\title{
Is the dual-support system really immutable?
}

Is a time of no-growth one for holding the line and stabilising institutions against erosive forces, or is it one for shaking up the system, bringing in reforms and generally ensuring that if and when growth returns a new structure is there to take advantage of it? This is a frequent question, in one of its many guises, which was asked last week by $\mathrm{Mr}$ Gerry Fowler, Minister of State at the Department of Education and Science when addressing heads of university chemistry departments on future government policy for scientific research. And, as if to underline the no-growth theme, later in the week the government announced that although the universities' recurrent grant for day-today expenditure would rise $11 \%$ to $£ 581$ million in 1976-7, this figure would be a cash limit, not to be supplemented (as in the past) for additional academic salary rises.

Mr Fowler gave the impression that his department had a fairly open mind on some of the major policy issues, or at least that views were still welcome on such matters as the customer-contractor principle, the quinquennial system and the dual-support system for university research. He also resurrected the question that many universities have been studiously avoiding for a long time: how to recognise more effectively the university teacher who is not inclined to do research as his primary occupation.

In the past year the dual-support system-the concept that one organisation gives general grants to

\section{Don't despise the miracle}

Mr JoHN FAGAN of Glasgow, suffering from a stomach cancer, was on the verge of death. The doctors had given him up, and fully expected him to die within a day or two. But his fellow-parishioners from the Roman Catholic church of The Blessed John Ogilvie were busy praying to John Ogilvie, who had been executed in 1615 for refusing to recognise the supremacy of King James I on spiritual matters. Mr Fagan survived. Nobody could find any physical cause for the dramatic turn-around in his health, and now the Roman Catholic Church has accepted the cure as miraculous and set John Ogilvie on the way to becoming a saint. At which you might expect us to sneer.

After all, there are plenty of cases where remission has occurred inexplicably; one-in-a-million chances do turn up once every million times. And what about all those cases, not given publicity by the church, where saints have been prayed to and have failed to deliver a cure? Surely in a world of scientific objectivity there support universities and provide a 'well-found' base for another organisation to support specific research projects -has been given some fairly widespread support. A Commons select committee has positively been angling for criticism of the system but has found relatively little; such criticism as there has been has tended to be about alleged shabby treatment by one arm or the other rather than about the concept as such. So should we all settle back and let the system run on as it is?

There seem to be two defects which have not been adequately discussed yet. The first was raised by $\mathrm{Mr}$ Fowler himself - the university teacher. The dualsupport system should offer every encouragement to the teacher who wishes only to take advantage of the well-found base and not to go after research council money. But somehow academics have got it into their heads that the badge of office is incomplete without a research grant. Second, although the system should be a support to the teacher, it can very easily be a shelter to the mediocre whose proposals to research council are regularly turned down. There has recently been much talk, not all of it malevolent, about eliminating mediocre people, departments or even universities. At present the machinery for so doing would be cumbersome in the extreme. One prop can be knocked out, but hardly both simultaneously. Would any modification of the present system of financial support provide a more challenging environment without making the rôle of the teacher even more insecure? can be no room for the miracle cure; the church is capitalising on rare and random phenomena.

This laboratory-bench view shows well the limited horizons that we may impose on ourselves. For we cannot yet cure cancer, least of all of the advanced sort that Mr Fagan was afflicted with, in spite of the hundreds of thousands of man-years devoted to scientific study of the subject; does that allow us to pass judgement on others who are also groping, but in entirely different territory? It does not.

It might if we were successful in curing cancer and if the church were actively dissuading its members from accepting medical treatment as a substitute for prayer to the saints. It might if the church were, as do many purveyors of quack cures, to claim a high success rate and to demand a large fee. Until then it were better that saints and scientists co-exist and be thankful for any small mercy, whether it be Mr Fagan's cure or a flash of insight accorded to some cancer researcher. 